\title{
Effect of Maize Production in a Changing Climate: Its Impacts, Adaptation, and Mitigation Strategies through Breeding
}

\author{
KL Naveenkumar, D Sen and VK Khanna* \\ College of Post Graduate Studies, Central Agricultural University, India
}

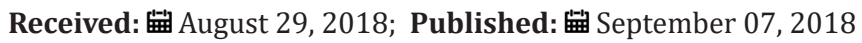

*Corresponding author: VK Khanna, School of Crop Improvement, College of Post Graduate Studies, Central Agricultural University, Barapani, Meghalaya, India

\begin{abstract}
Increasing the population and off them living styles effect on the surrounding environment leads to changes in climate with time. In the long run, the climatic change could affect agriculture in several ways such as quantity and quality of crops in terms of productivity, growth rates, photosynthesis and transpiration rates, moisture availability etc. Among the agricultural crops maize is also one of the most important food crops. Predictions suggest that worldwide climate change will reduce maize production this will coincide with a substantial increase in demand for maize due to rising populations. However, selection for climate change adaptation cultivar is difficult due to complex genotype by environment interactions. The broader use of traits from alien species and the manipulation of heterosis and polyploidy create new perspectives for improving yield potential and adaptation to climate change. Maize research has a crucial role to play in enhancing adaptation and mitigation of climate change while also enhancing food security. The varieties of maize hybrids with increased tolerance to heat and drought stress and resistance to pests and diseases are serious for handling existing climatic variability and for adaptation to progressive climate change.
\end{abstract}

Keywords: Abiotic stress; Environment; Heterosis and Polyploidy

\section{Introduction}

Over the next 50 years agriculture must provide for an additional 3.5 billion people Borlaug [1]. Production of the three major cereal crops alone (maize, wheat and rice) will need to increase by $70 \%$ by 2050 in order to feed the world's growing rural and urban populations. However, climate change scenarios show that agricultural production will largely be negatively affected and will impede the ability of many regions to achieve the necessary gains for future food security Lobell et al. [2]. Climate change refers to the increase of earth's temperature due to the release of gases such as $\mathrm{CO}, \mathrm{CH}, \mathrm{CFCs}$, NO and $\mathrm{O}$ into the earth's atmosphere IPCC [3]. Climate variability has been and continues to be, the principal source of fluctuations in global food production in countries of the developing world and is of serious concern. The mean annual rainfall is considerably low in most parts of the world and temporal variability is quite high. Climate change impacts on agricultural crop production vary from place to place and from crop to crop.
Climatic factors such as temperature, precipitation, moisture and pressure affect the development of plants, either alone or by interacting with other factors. This implies that rural sustenance and food security is under threat along with socioeconomic stability Burke et al. [4], and ecological integrity Walker and Schulze [5]. These risks are particularly high for the less resilient impoverished countries. Considerable research work has been carried out on the effects of weather/climate on agricultural production, but few works have been specific on the effects of climate change on maize production. Maize is one of the most important staple food crops in the world after wheat and rice and belongs to the family Poaceae. Maize occupies an important position among the crops, both as food and feed as well as raw material in industrial production of starch, oil, protein, alcoholic beverages, biofuel, food sweeteners, pharmaceuticals, cosmetics, films, textiles, gums, and also in packaging and paper industries, etc. It is the most versatile photo- insensitive crop with high adaptability which is why maize 
is referred to as "Miracle Crop". Being a C4 plant, it is physiologically more efficient, has higher grain yield potential compared to other grass family members and is also regarded as "Queen of Cereals". Maize crop as such has multiple uses. The kernel contains about 77 per cent starch, two per cent sugar, nine per cent protein, 2 per cent ash on a water-free basis, five per cent Pentosan (sold for the relief of many medical conditions including thrombi and interstitial cystitis in humans and osteoarthritis in dogs and horses) and five per cent oil. Maize Oil is considered as the highest containing poly unsaturated fatty acid (PUFA), linoleic acid (61.9\%). So, it remains a liquid at fairly low temperatures which is helpful in combating heart diseases (Figure 1). Maize oil is also low in linolenic acid (0.7\%) and contains a high level of natural flavour. Maize is used primarily as a food for humans in most areas of the world, in contrast to the United States where about 85 per cent of the crop is used as cattle feed.

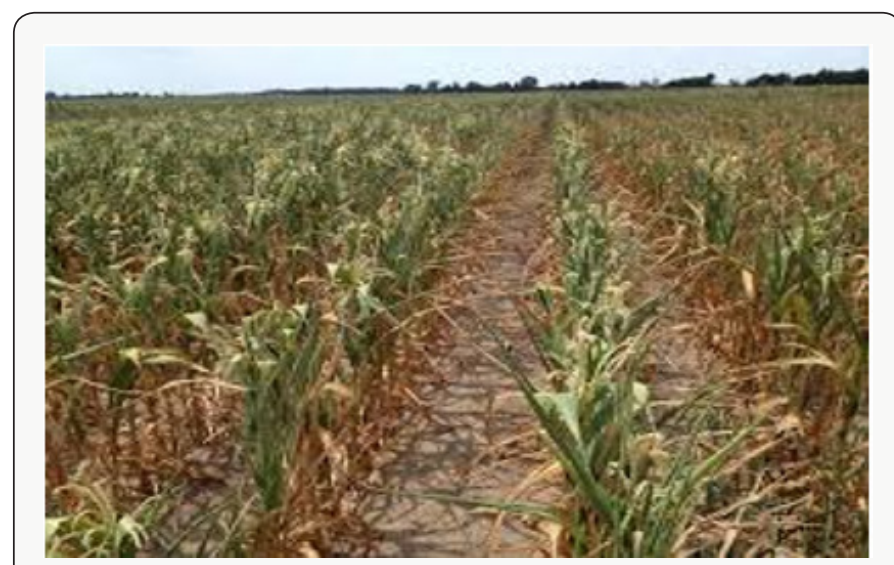

Figure 1: Severe drought in maize field.

\section{Effects of Climate Variability and Change on Maize Growth}

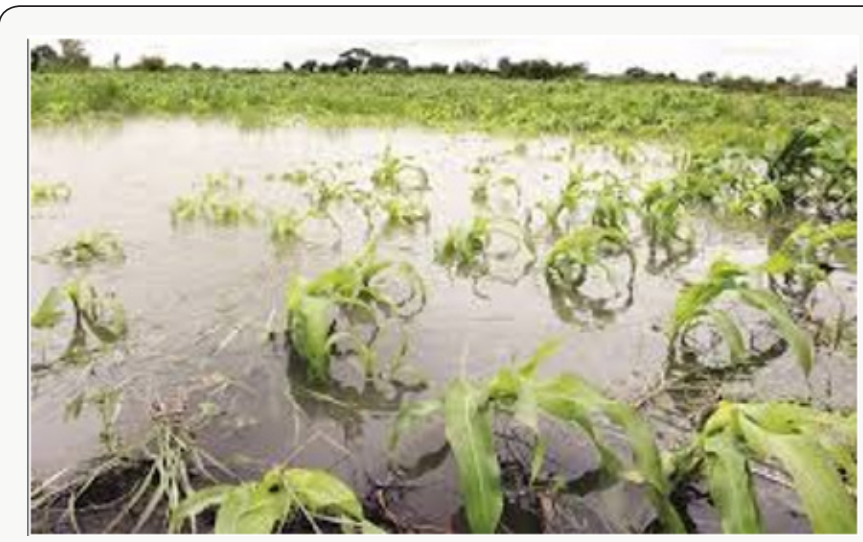

Figure 2: Water logging in maize field.

Climate variability affects maize yield and the various crop processes and activities in maize production. There has been a significant fluctuation in maize yield and production. The occurrence of extreme climate variability such as may be characterized by a prolonged dry period or heavy rainfall spell coinciding with the critical stages of crop growth and development may lead to significantly reduced crop yields and extensive crop losses (Figure 2). Maize production has been on steady decline due to erratic rainfall variability and the area planted to maize has also been reduced to adapt to the anticipated drought period.

\section{Effects of Climate Variability in Relation to Biotic and Abiotic Stress}

Due to global warming, and potential climate abnormalities associated with it, crops typically encounter an increased number of abiotic and biotic stress combinations, which severely affect their growth and yield. Concurrent occurrence of abiotic stresses such as drought and heat has been shown to be more destructive to crop production than these stresses occurring separately at different crop growth stages. Abiotic stress conditions such as drought, high and low temperature and salinity are known to influence the occurrence and spread of pathogens, insects, and weeds. They can also result in minor pests to become potential threats in future Duveiller et al. [6]. These stress conditions also directly affect plant-pest interactions by altering plant physiology and defence responses (Figure 3). Additionally, abiotic stress conditions such as drought enhance competitive interactions of weeds on crops as several weeds exhibit enhanced water use efficiency than crops.

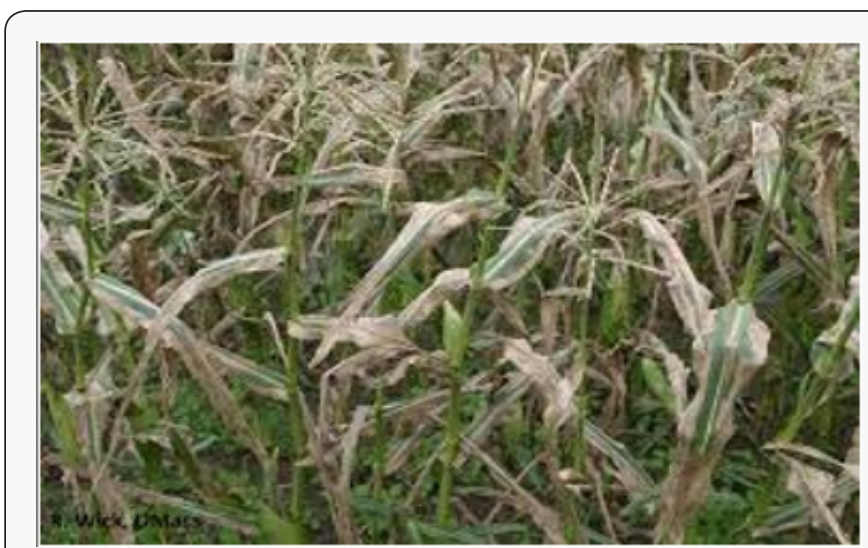

Figure 3: Severe infection of Northern corn leaf blight (NCLB) in a maize field.

\section{Abiotic Stresses of Maize Under the Changing Climate}

Drought: Drought is the most pervasive limitation to the realization of yield potential in maize (Edmeades et al. [7]). Average annual global losses due to drought in maize range from $15 \%$ in temperate zone to $17 \%$ in tropical zone as estimated by empirical methods. A precise measurement of yield losses worldwide is not possible due to a range of occurrences of drought from individual fields to regional in extent, with severity from slight to catastrophic. Losses are greatest in parts of the world where soils and weather patterns are less favourable than US Corn Belt, which is named for its long-term suitability for growing maize at relatively low level of risk of crop failure. 
Heat: By the end of this century, growing season temperatures will exceed the most extreme seasonal temperatures recorded in the past century Battisti and Naylor [8]. Using crop production and meteorological records, Thomson [9] showed that a $6^{\circ} \mathrm{C}$ increase in temperature during the grain filling period resulted in a $10 \%$ yield loss in the US Corn Belt.A later study in the same region showed maize yields to be negatively correlated with accumulated degrees of daily maximum temperatures above $32^{\circ} \mathrm{C}$ during the grain filling period. Lobell and Burke [10] suggested that an increase in temperature of $2^{\circ} \mathrm{C}$ would result in a greater reduction in maize yields within subSaharan Africa than a decrease in precipitation by $20 \%$. A recent analysis of more than 20,000 historical maize trial yields in Africa over an eight year period combined with weather data showed for every degree day above $30^{\circ} \mathrm{C}$ grain yield was reduced by $1 \%$ and $1.7 \%$ under optimal rainfed and drought conditions, respectively Lobell et al. [11]. The temperature threshold for damage by heat stress is significantly lower in reproductive organs than in other organs

Stone [12]. Successful grain set in maize requires the production of viable pollen, interception of the pollen by receptive silks, transmission of the male gamete to the egg cell, and initiation and maintenance of the embryo and endosperm development Schoper et al. [13]. High temperature during the reproductive phase is associated with a decrease in yield due to a decrease in the number of grains and kernel weight. Under high temperatures, the number of ovules that are fertilized and develop into grain decreases.

Water Logging: Over 18\% of the total maize production area in South and Southeast Asia is frequently affected by floods and water logging problems, causing production losses of $25-30 \%$ annually Zaidi and Singh [14]. Although the area of land in sub-Saharan Africa affected by water logging is lower than in Asia, it is a risk in a few areas. Water logging stress can be defined as the stress inhibiting plant growth and development when the water table of the soil is above field capacity. The diffusion rate of gases in the flooded soil could be 100 times lower than that in the air, leading to reduced gas exchange between root tissues and the atmosphere Armstrong and Drew [15]. As a result of the gradual decline in oxygen concentration within the rhizosphere, the plant roots suffer hypoxia (low oxygen), and during extended water logging (more than 3 days), anoxia (no oxygen) Zaidi and Singh [14]. Carbon dioxide, ethylene and toxic gases (hydrogen sulphide, ammonium and methane) also accumulate within the rhizosphere during periods of water logging. A secondary effect of water logging is a deficit of essential macronutrients (nitrogen, phosphorous and potassium) and an accumulation of toxic nutrients (iron and magnesium) resulting from decreased plant root uptake and changes in redox potential. Nutrient uptake is reduced as a result of several factors. Anaerobic conditions reduce ATP production per glucose molecules, thereby reducing energy available for nutrient uptake. Reduced transport of water further reduces internal nutrient transport. Reduced soil conditions decrease the availability of key macro nutrients within the soil. Under water logging conditions nitrate is reduced to ammonium and sulphate is converted to hydrogen sulphide, and both become unavailable to most of the non-wetland crops, including maize. Availability of phosphorous may increase or decrease depending upon soil pH during water logging.

Biotic Stresses of Maize Under the Changing Climate: Abiotic stresses account for a significant proportion of maize yield losses worldwide. The predominant insect-pests and diseases vary across environments and a major challenge in adapting crops to climate change will be the maintenance of genetic resistance to pests and diseases Reynolds and Ortiz [16]. Changing climates will affect the diversity and responsiveness of agricultural pests and diseases. Studying and understanding the drivers of change will be essential to minimize the impact of plant diseases and pests on maize production.

Plant Diseases: For a disease to occur a virulent pathogen, susceptible host and favourable environment are essential Legrève and Duveiller [17]. All of these components are strongly coupled with environmental conditions. Global climate changes have the potential to modify host physiology and resistance, and alter both stages and rates of pathogen development. Environmental conditions controlling disease development include rainfall, relative humidity, temperature and sunlight. Changes in these factors under climate change are highly likely to have an effect on the prevalence of diseases and emergence of new diseases. For example, in Latin America tar spot complex, caused by Phyllachora maydis, Monographella maydis and Coniothyrium phyllachorae, was previously rare. However, recent epidemics of the tar spot complex have been recorded in Guatemala, Mexico, Colombia and El Salvador due to recent climate variability Pereyda-Hernández et al. [18]. Climate change may also affect gene flow, the process through which particular alleles or individuals are exchanged among separate populations. This will increase pathogen population diversity leading to variation in host resistance, variation in pathogen virulence and new specific interactions. This has the potential to result in new diseases or pathogen emergence, and the introduction of pathogens into new ecological niches. Depending on the distribution of populations and environmental conditions that are influenced by climate change, gene flow leads to an increase in population diversity or to the introduction of a new population in new ecological niches. An important example of changes in growing season conditions being linked to outbreaks of diseases, with serious human health implications, is mycotoxins and their prevalence within maize systems. Mycotoxins are toxic secondary fungal metabolites that contaminate agricultural products and threaten food safety. Different groups of mycotoxins are produced by different fungi. A. flavus and A. parasiticus produce aflatoxin, F. verticillioides produces fumonisin, and F. graminierum produces deoxynivelanol (DON) and zearalenone) Cardwell et al. [19]; 
Miller [20]. Mycotoxin contamination is a serious problem with long-term consequences for human and animal health. Sub-lethal exposure to mycotoxins suppress the immune system, increase the incidence and severity of infectious diseases, reduce child growth and development, and reduce the efficacy of vaccination programs Williams et al. [21]. Consumption of high doses of mycotoxins causes acute illness and can prove fatal. In 2004, more than 125 people died in Kenya from eating maize with aflatoxin B1 concentrations as high as 4,400 parts per billion - 220 times the Kenyan limit for foods Lewis et al. [22]. The maize implicated in this outbreak was harvested during unseasonable early rains and stored under wet conditions conducive to mold growth and therefore aflatoxin contamination CDC [23]. Previous outbreaks in Kenya and India have also been attributable to unseasonable, heavy rain during harvest Krishnamachari et al. [24]; Ngindu et al. [25].

Insect-Pests: The dynamics of insect-pests are also strongly coupled with environmental conditions. Insects do not use their metabolism to maintain their body temperature, and are dependent on ambient temperature to control their body temperature. Temperature is therefore the single most important environmental factor influencing insect behaviour, distribution, development and survival, and reproduction. Insect life stage predictions are calculated on accumulated degree days, which is a function of both time and temperature. Increased temperature can speed up the life cycle of insects leading to a faster increase in pest populations. It has been estimated that a $2^{\circ} \mathrm{C}$ increase in temperature has the potential to increase the number of insect life cycles during the crop season by one to five times Petzoldt and Seaman [26]; Bale et al. [27]; Porter et al. [28]. The feeding rate of many arthropod vectors increases at higher temperatures, thus increasing exposure of crops to mycotoxigenic fungi thereby increasing the spread of mycotoxins Bale et al. [27]; Dowd [29]. The increased global warming and drought incidences will favour insect proliferation and herbivory, which will likely increase the incidence and severity of insect related damages as well as aflatoxin and fumonisin mycotoxins in maize. Higher average temperatures have the potential to change the geographical distribution of crops. This may in turn result in an expansion of the geographical distribution of insect-pests and their associated pathogens (e.g. maize streak virus, corn stunt complex that are vectored by different species of leaf hoppers), resulting in a change in the geographical distribution of diseases.

Strategies for Mitigating Climate Related Effects of Biotic Stresses on Maize Yields: Breeding for disease and insect resistance requires an understanding of parasite biology and ecology, disease cycles and drivers influencing the evolution of plant-pathogen interactions, because unlike abiotic stresses, biotic stress resistance is influenced by genetic variability in the pest/ pathogen population. As a result of the evolving pest/pathogen populations and the changes in fitness favouring new pathotypes/ biotypes, improving resistance to biotic stresses has been a long- term focus of agricultural researchers. The long-term success of conventional and molecular breeding for disease or insect-pest resistance will depend on a more in-depth and clear understanding of: (i) the nature of the pathogen/insect-pest, and diversity of virulence in the populations; (ii) the availability, diversity and type of genetic resistance; (iii) availability of suitable sites (hot spots), screening methodologies/protocols for generating adequate disease/insect-pest pressures and tracking resistance; (iv) selection environments and methodologies for rapidly generating multiple stress resistant inbred lines, and their use in hybrid or variety development. Significant progress has been made over the decades in the identification of stable genetic resistance for major maize diseases Dowswell et al. [30]. However, the population structure of most maize pathogens remains inadequately characterized. Also, concerted efforts are required to widely test the available sources of resistance in multiple and relevant environments to expose them to a wide spectrum of pathogen strains and to facilitate identification of the most suitable resistance genes/alleles for use in the breeding programs [31]. Research at CIMMYT is focused on multi-location phenotyping of a common set of 500 maize inbred lines for some prioritized diseases, namely GLS (gray leaf spot), TLB (Turcicum leaf blight), MSV (maize streak virus), and ear rots, across more than 15 locations in Sub-Saharan Africa, Latin America and Asia. This will help identify stable sources of resistance to key diseases and identify key phenotyping sites for future research. Using a common set of genotypes across environments will also provide the ability to monitor and detect emergence of new pathogen strains that will be registered as shifts in disease pressure and emerging new diseases, and how the environmental characteristics impacts pest biology and prevalence. CIMMYT has also developed several insectpest resistant populations, inbred lines, and varieties, especially for the stem borers and post-harvest insect pests (weevils and grain borers) through projects such as Insect Resistant Maize for Africa (IRMA). In addition, several inbred lines have been developed combining resistance to stem borers and storage pests.

\section{Conclusion}

Adaptation to climate change requires cross-disciplinary solutions that include the development of appropriate germplasm and mechanism to facilitate to farmers access to germplasm. Seed production and deployment, effective policies and management strategies at the country, regional and international levels will all be required to ensure that the technologies reach the intended beneficiaries and make the desired impacts. Varieties with increased resilience to abiotic and biotic stresses will play an important role in autonomous adaptation to climate change. Over fifty years ago scientists were able to offset yield losses by up to $40 \%$ through the development of improved germplasm and management options. Today, scientists are faced with an even harder challenge-to meet the needs of future generations in the face of both population growth and climate change. While this challenge is immense, the 
advancement in molecular and phenotyping tools combined with the vast accumulated knowledge on mechanisms responsible for yield loss will provide a solid foundation to achieve increases in productivity within maize systems.

\section{References}

1. Borlaug N (2007) Feeding a Hungry World. Science 318(5849): 359.

2. Lobell DB, Burke MB, Tebaldi C, Mastrandrea MD, Falcon WP, et al. (2008) Prioritizing climate change adaptation needs for food security in 2030. Science 319(5863): 607-610.

3. IPCC, Fourth Assessment Report: Synthesis, published online 17 November 2007.

4. Burke MB, Lobell DB, Guarino L (2009) Shifts in African crop climates by 2050 , and the implications for crop improvements and genetic resources conservation. Global Environ Change 19(3): 317-325.

5. Walker, Schulze EW (2008) One degree increments in soil temperatures affect maize seedling behaviour. Proc Soc Soil Sci Am 33: 729-736.

6. Duveiller E, Singh R, Nicol J (2007) The challenges of maintaining wheat productivity: pests, diseases, and potential epidemics. Euphytica 157(3): 417-430.

7. Edmeades GO, Bolaños J, Hernandez M, Bello S (1993) Causes for silk delay in lowland tropical maize population. Crop Sci 33: 889-913.

8. Battisti DS, Naylor RL (2009) Historical warnings of future food insecurity with unprecedented seasonal heat. Science 323: 240-244.

9. Thomson LM (1966) Weather variability, climate change and grain production. Science 188(4188): 535-541.

10. Lobell DB, Burke MB (2010) On the use of statistical models to predict crop yield responses to climate change. Agric. Forest Metero 150: 14431452.

11. Lobell DB, Bänziger M, Magorokosho C, Vivek B (2011) Nonlinear heat effects on African maize as evidenced by historical yield trials. Nature Climate Change 1: 42-45.

12. Stone P (2001) The effects of heat stress on cereal yield and quality. In Crop Responses and Adaptations to Temperature Stress. (AS Basara, Ed.), Food Products Press, Binghamton, New York, USA, pp. 243-291.

13. Schoper JB, Lambert RJ, Vasilas BL (1987a) Pollen viability, pollen shedding, and combining ability for tassel heat tolerance in maize. Crop Sci 27(1): 27-31.

14. Zaidi PH, Singh NN (2010) Effect of waterlogging on growth, biochemical compositions and reproduction in maize. J Plant Biol 28: 61-69.

15. Armstrong W, Drew MC (2002) Root growth and metabolism under oxygen deficiency. In Plant roots: the hidden half ( $\left.3^{\text {rd }} E d n\right)$, A Eshel and U Kafkafi (Eds.), Marcel Dekker, New York, USA, pp. 729-761.

16. Reynolds MP, Ortiz R (2010) Adapting crop to climate change: A summary. In Climate change and crop production. Curr Opin Plant Biol 11: 171-179.
17. Legrève A, Duveiller E (2010) Prevailing potential disease and pest epidemics under a changing climate. In climate change and crop production, CABI press, Europe, pp. 263-283.

18. Pereyda Hernández J, Hernandez Morales J, Sandoval Islas S, Aranda Ocampo S, De León C (2009) Etiología y manejo de la mancha de asfalto (Phyllachora maydis Maubl.) del maízen Guerrero, México. Agrociencia 43(5): 511-519.

19. Cardwell KF, Desjardins A, Henry SH, Munkvold G, Robens J (2001) Mycotoxins: the cost of achieving food security and food quality.

20. Miller JD (2008) Mycotoxins in small grains and maize. Food Additives Contam 25: 219-230.

21. Williams JH, Phillips TD, Jolly PE, Stiles JK, Jolly CM, et al. (2004) Human aflatoxicosis in developing countries: a review of toxicology, exposure, potential health consequences, and interventions. Am J Clin Nutr 80: 1106-1122.

22. Lewis L, Onsong M, Njapau H, Schurz-Rogers H, Luber G, et al. (2005) And the Kenyan Aflatoxicosis Investigation Group. Aflatoxin contamination of commercial maize products during an outbreak of acute aflatoxicosis in Eastern and Central Kenya. Environ. Health Prospect 113(12): 17631767.

23. CDC (Centers for Disease Control and Prevention) (2004) Outbreak of aflatoxin poisoning eastern and central provinces, Kenya, January-July, 2004. MMWR Morb Mortal Wkly Rep 53(34): 790-792.

24. Krishnamachari KA, Nagarajan V, Ramesh VB, Tilak TBG (1975) Hepatitis due to aflatoxicosis: an outbreak in Western India. Lancet 305: 1061-1063.

25. Ngindu A, Johnson BK, Kenya PR, Ngira JA, Ocheng DM, et al. (1982) Outbreak of acute hepatitis caused by aflatoxin poisoning in Kenya. Lancet 319(8285): 1346-134.

26. Petzoldt C, Seaman A (2005) Climate change effects on insects and pathogens. Climate Change and agriculture: promoting practical and profitable responses.

27. Bale JS, Masters GJ, Hodkinson ID, Awmack C, Bezemer TM, et al. (2002) Herbivory in global climate change research: direct effects of rising temperatures on insect herbivores. Global Change Biol 8: 1-16.

28. Porter JH, Parry ML, Carter TR (1991) The potential effects of climatic change on agricultural insect pests. Agricult. Forest Meteor 57: 221-240.

29. Dowd PF (1992) Insect interactions with mycotoxin-producing fungi and their hosts. In insect interactions with mycotoxin-producing fungi and their hosts (D Bhatnagar, EB Lillehoj and DK Arora, Eds.), Marcel Dekker, New York, USA, pp. 137-155.

30. Dowswell CR, Paliwal RL, Cantrell RP (1996) Maize in the third world. Westview Press Inc. Boulder, Colorado, USA Ed.) Academic Press, London, UK, p. 9-45.

31. Engelen Eigles G, Jones RJ, Phillips RL (2000) DNA endo-reduplication in maize endosperm cells: the effect of exposure to short-term high temperature. Plant Cell Environ 23: 657-663. 
(c) (P) This work is licensed under Creative Commons Attribution 4.0 License

To Submit Your Article Click Here: $\quad$ Submit Article

DOI: $10.32474 /$ OAJOM.2018.02.000142

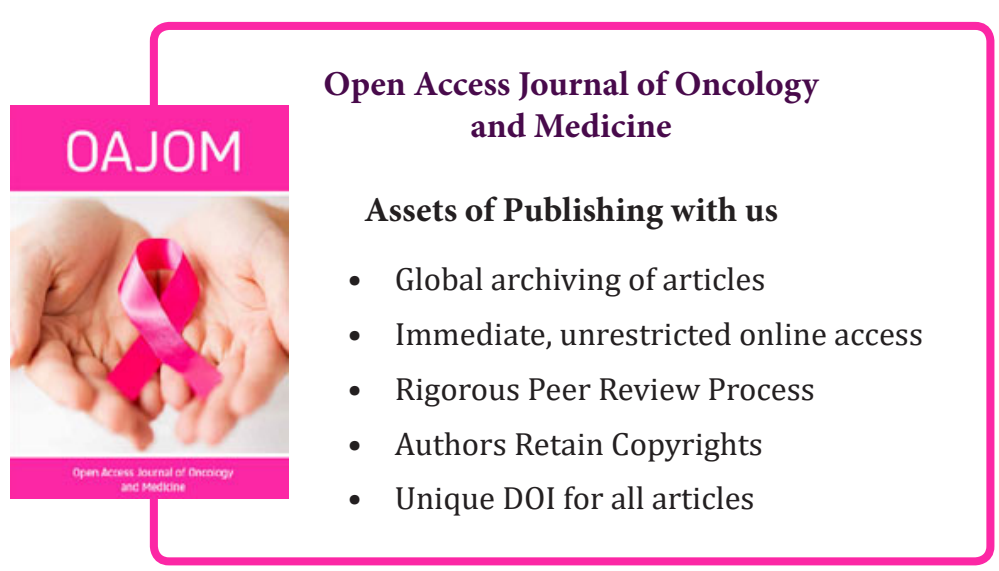

